\title{
The Role of Management in Increasing Students' Satisfaction: Investigating Culture, Price and Reputation of Universities of Pakistan
}

\author{
Urooj Fatima, PhD \\ School of Education, Huazhong University of Science and Technology, \\ Wuhan, China \\ Zhang Junchao, PhD \\ Professor, Voice Dean of School of Education, Huazhong University of \\ Science and Technology, Wuhan, China \\ Daniyal Khan, MBA \\ Management Sciences, Pakistan Institute of Economics and Technology, \\ Karachi, Pakistan
}

\begin{abstract}
Title: this research paper investigates the role of university management in increasing students' satisfaction by checking the role of culture, price and reputation of universities of Pakistan. Management qualities of a university plays an important role in the development of students' satisfaction, and directly or indirectly influences their satisfaction level. It is argued that university management should focus on culture development and lowering down tution price to increase satisfaction level and reputation of the university. This study made use of 5-point Likert scale questionnaire to find out the management quality factors. A total of 150 students from different universities were investigated through this questionnaire. SPSS 21 software was used for the investigation through regression and correlation analysis. Convenience sampling method was used, due to lack of time and resources for approaching the respondents. Only the university respondents were inquired to find out their satisfaction level. The results obtained were segmented into six hypothesis. Five hypothesis were accepted. It was found that students were not satisfied with management quality and culture of their universities. While correlation between management quality and students' satisfaction was found positive. The students are not happy with service timing and its quality provided by the university management. The relationship between university reputation and management quality through correlation was found to be negative. Tution fee of the investigated universities is very high, which is also a reason students' do not like service quality even after paying high fees.
\end{abstract}


Keywords: Students Satisfaction, Pakistan, Culture, Price, Reputation

\section{Introduction}

Checking quality in Higher Educational Institutions (HEIs) is considered a complex phenomenon. It demands investigation of two important points to focus, Management quality and academic quality. According to the research article of Ud Din and Saeed (2019), the academic quality focuses on learning outcomes, which acquires and aims to improve both the abilities and knowledge of the students in various subject domains. On the other hand, Management quality depends on institutional Managements, comprising of both tangible and non-tangible features (Ud Din \& Saeed, 2019). The weaker platform in terms of Management comprehension has concentrated their focus, and now the emphasis on measurable features, which include physical environment, assets and equipment.

Due to this weaker comprehension, Higher Education Commission (HEC), has generally funded more universities on this notion and evaluates their quality on same perceptions too. HEC is one of those governing bodies, inspecting quality of education in educational institutes regularly. It also provides guidelines and policies needed to be followed by universities. The study of Arif, Iqbal and Khalil (2019) argued that most of the institutes in Pakistan are in strong need to spend more on human infrastructure to strengthen their infrastructure. The latest statistics show that the number of educational institutes significantly inclined during 2010-2015 as reported by the study of Ferdousipour (2016). Therefore, with an increase in universities, the need for Management quality significantly increased to retain a high number of students. However, education standard has not been up with a rapid pace, because education is considered an important source in an economy, the economy of Pakistan did not improve.

According to the research article of Deming (2018), it is the responsibility of the government to provide quality education to students and support them with the help of quality education. Furthermore, quality depends on many parameters, which are done in collaboration of institution and government to increase education standards of an institute. The education sector of Pakistan is very weak as reported by Deming (2018) due to which the quality Management and education must be provided by the management of these institutions. This includes use of technology in the academics and funding for needy students.

A number of studies have been carried out to assess Management quality and student satisfaction among the university graduates, only a few of them investigated pricing and university reputation as determinants of 
Management quality. Shah (2013) argued that scarce literature is available in the context of Pakistan HEIs, in terms of moderator or mediator variables.

This research paper aims to provide an analysis of three factors, which are university culture, reputation and price as the moderators. While Management quality is kept as dependent variable and analyses the extent to which it satisfies the students, particularly in universities of Pakistan. The key objective of this study is identification of Management quality and its influence on student satisfaction rate, and its influence on universities. This study makes significant contributions to limited and scarce literature on this topic. When searching over the internet, only one study investigated the influence of price on Management quality of the universities, and that too back in 2010. This study identifies the gaps in Management quality of educational institutes, based on which the performance of the universities can improve in future.

Management quality is called as a contemporary conceptualization when the comparison between perceived expectations and perceived performance is needed to be analysed. According to the findings of Ali, Sulaiman and Javed (2018), Management quality is tough to measure, because of its intangible nature and consideration of all Management quality aspects. They suggested SERVQUAL, which is normally used to measure Management quality by critically evaluating five aspects, which include tangibles, reliability, responsiveness, assurance, and empathy (Ali, Sulaiman \& Javed, 2018).

Student satisfaction has defined an extent to which an organisation meets the needs of students and provides quality education (Dib \& Alnazer, 2013). The satisfaction level of the students is influenced by their expectations and their perceptions related to quality of Management provisions.

University culture is defined as the support and collaboration platform provided by the management of educational institutes to overcome the difficulties of students. However, Shah (2013) argued that each university has its own culture, and factors which comprise of elements and cultural aspects. University reputation provides a combined reputation of a university and multiple elements from internal and external factors. It also includes mediahold of the university, which is developed over a period of time.

\section{Research Questions:}

This research answers three questions. The first question evaluates, to what extent the student satisfaction is influenced by Management service quality and what is the relationship between them? The second question evaluates, what role does university reputation, price and culture play when association between Management quality and student satisfaction is needed to 
be evaluated? While the third question asks about the role of governmental and institutional factors in quality Management in the institutes?

\section{Research Design and Methodology:}

This research is based on quantitative approach and aims to analyse the role of all the factors by critically evaluating their relationship between them. Online survey questionnaires were distributed to the respondents of this study, who were students of different universities. The questionnaire was based on five-point Likert scale methodology.

\section{Conceptual Framework:}

Since it was reported by Uprety and Chhetri (2014) and Ali and Mohammed (2014) that Management quality significantly influences student satisfaction, only one study in Pakistan checked the role of Management quality on students satisfaction by investigating culture, price and reputation as the mediating factors. In addition, the role of government and institutions is also analysed in terms of quality management practices followed in the universities. This study makes use of the following theoretical framework:

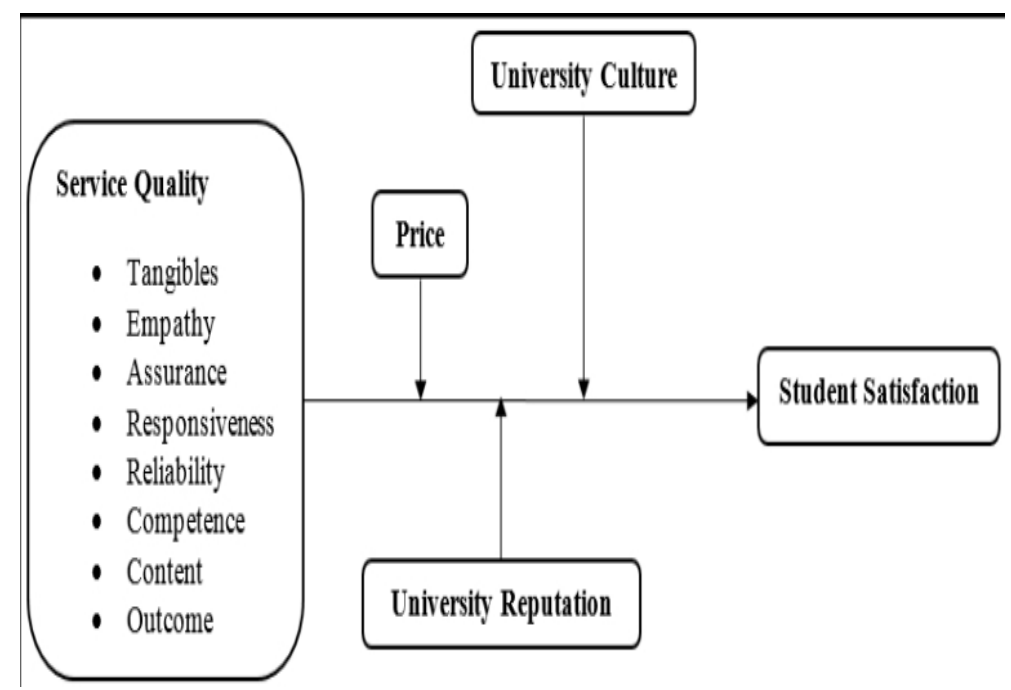

Figure 1. Theoretical framework

Based on the combination of above factors in institutional development, this study comes up with a theory of "New Institutionalism". The focus of this theory would be on the development of structures of support for the workers. In addition, this theory would focus on increasing the development of new principles for social behaviours of the management people in universities. Different elements of this theory have been drawn from the interviews conducted, and the problems they face in managing the students. 


\section{Hypothesis}

\begin{tabular}{|c|}
\hline $\begin{array}{c}\text { Management quality and students' satisfaction are positively } \\
\text { associated. }\end{array}$ \\
\hline University reputation influences students' satisfaction \\
positively.
\end{tabular}

\section{Literature Review:}

This chapter is segmented into two parts. First part provides critical review of all the variables and their relationship with each other. While second part provides the assessment of literature gap, which would be reduced by this study.

\section{Management Quality:}

According to the research article of Arif, Iqbal and Khalil (2019), Management quality is one of the most used parameters by the educational institutes in different nations, because it provides a critical review of different parameters, which support educational developments. Management quality keeps on changing according to the situations of different nations, in which a nation operates. However, Ntabathia (2013) argued that Management quality cannot be measured to perfection because of its intangible nature, therefore, all the aspects of Management quality should be taken into consideration. The studies have argued that SERVQUAL is a good model to measure customer satisfaction, however, SERVQUAL needs more generalization.

\section{Student Satisfaction:}

Student satisfaction depends on a number of parameters and keeps on changing according to their lifestyles. For example, Ntabathia (2013) argued that some students demand that quality education should be provided to them with the induction of technology, while some demand that prices should be low. Arguing with the statement, Shah (2013) wrote that most of the students in Pakistan want that high paying institutions should lower their fee structure because most of the people in Pakistan cannot afford them. in addition, when students come in the universities, they expect that university works will be quick, and support staff would be there to provide them with quality Management (Shah, 2013). Therefore, these are some of the Management parameters, influencing the Management quality and satisfaction rate of the 
customers. Andam, Montazeri, Feizi and Mehdizadeh (2015) supported the statement of Azizi, Kapak and Tarhandeh (2014) and argued that reputation of educational institutes is an important consideration when student satisfaction rate is needed to be analysed. The satisfied students always generate optimistic views on institution level and present same reviews to other students.

\section{University Culture:}

With the passage of time, the management of various institutions is getting aware of the culture and its importance in the educational institutes. In an investigation presented by Andam et al., (2015), the authors reported that university culture significantly diversifies the institutions and provide them with the awareness of culture. If the management focuses on provision of more and more Management platforms, it becomes easier for them to analyse their role in university development, and increase Management quality. Nonetheless, Babaei, Rahimian, Ahmad, Omar and Idris (2015) did not support the argument completely and wrote that most of the universities have their own elements of culture, which must be interconnected according to the cultural aspects. In short, university culture works like a web, where administration plays an important role to keep everyone updated and connected. Therefore, it can be argued that most of the universities should significantly assist the management to develop a culture of collaboration and support by the management to generate high number of revenues and satisfied students.

\section{University Reputation:}

University reputation is based on a combination of multiple elements, segmented into internal and external elements. The findings of Kordshouli, Jafarpour and Bouzanjani (2016) showed that university reputation normally depends on five parameters, which are visibility, distinctiveness, authenticity, transparency and consistency. If the university management aims to increase the association between corporate visual identity and corporate reputation, the researchers reported that a university's reputation can be directly or indirectly mediated and improved. However, Sin, Yousuf and Sin (2018) wrote that most of the people working in the universities need to maintain a good relationship with the students to become a reputable university or else. Researchers reported that a university's reputation can be directly or indirectly influenced according to mediated experiences.

A number of studies tried to identify and recognize the importance of university reputation and its importance. According to the findings of $\mathrm{Xu}$ and Du (2018), most of the students select the universities based on the reputation level of that specific university, however, the reputation of university depends on more than one parameters. They further added that reputation can mostly 
be perceived by looking into both horizontal and vertical directions (Xu \& Du, 2018). According to them, horizontal context of reputation depends on comparison between the institutions based on some specific characteristics and dimensions, which a student appreciates. On the other hand, Sin, Yousuf and Sin (2018) explained vertical context of reputation as dealing with the student's perception according to positive and negative emotions. Therefore, these positive and negative emotions allow in evaluation of university reputation and improve it.

\section{Price:}

Price depends on purchasing of commodities and Managements by spending money. $\mathrm{Xu}$ and $\mathrm{Du}$ (2018) narrated price by observing consumer perceptions as the major influencing character to let go of something in order to get a commodity or a Management. While, Raza, Qazi and Shah (2018) explained the concept of price as fairness and procedure through which rational outcomes can be sustained. For example, when price is fair and according to the view of customers, then it can be called as fairly charged. They added on the argument that most of customer mostly go for fairly charged products and avoid getting the expensive one. However, customer contentment can be determined by observing perceived price also.

The factors identified in various studies for identification of price of the students can be looked by observing various factors such as tuition fees, books costs and the coaching material. Arif, Ameen and Rafiq (2018) argued that if customers or university students are satisfied with these identified factors, they rate university as a quality university ultimately influencing satisfaction level. However, Fatima and Khero (2019) argued that there is a dissimilarity between these concepts, because of price, Management quality and customer contentment. Therefore, the inter-relationships can significantly influence customer satisfaction, price and quality to make it interesting to study all the three concepts.

\section{Reflections and Summary:}

This section provided a critical review of all the factors identified in conceptual framework and also evaluates the relationship between them. based on the arguments observed, it can be argued that all the factors showed a significant positive relationship with dependent variable, hence the methods used to asses them are explained in next chapter.

\section{Research Methodology:}

This study is a mixed-method study because it uses both interview and survey questionnaire. This study is based on adapting to convenience sampling approach to select the number of respondents. Convenience sampling was 
used to save time and reduce expenses. The findings from the questionnaire are also evaluated by comparison with available literature. First survey and interview methodology were chosen and then questionnaires were developed. Next questionnaires were distributed to the university students according to the convenience. Friends and their friends were used for collecting the responses and survey was stopped when 150 responses reached. The questionnaire was based on five-point Likert scale methodology and comprised of 8 questions in total. Each factor was evaluated with the help of 2 questions. The interview questionnaire comprised of 5 questions based on selected theory.

When an investigation is needed to be carried out, it becomes important to select one of the best methods to carry out investigation. This study applied correlation and regression method to find out the relationship between dependent and independent variables. Interview results were based on content analysis methodology. Each hypothesis is separately covered and evaluated. The variables analysed for the questionnaire were shown to the supervisor to increase validity and reliability of the studies. Furthermore, students willing to participate with mutual consent were involved in the survey. Only the participants willing to participate in online questionnaire were involved, and their names were not taken. Only the university students and professors were approached for completion of surveys and the management was approached for permission. Research ethics were further deployed by the investigator to ensure that all the activities and responses are received on time.

This research employs the understanding of various concepts, which underpin a method of quantitative approach. It is the responsibility of the management to ensure that high-quality service is being provided to the students because it would make it easier for them to study with full concentration and not get worried related to their studies. It would assist them to ensure that all the problems related to the management perspective allow them to ensure that they focus on personal development, rather than getting worries for academic service quality. While the qualitative approach provides assessment of the weaknesses and service level in these universities. The management of different universities would be able to improve their service quality, by looking into the theory proposed by this research.

\section{Findings:}

\section{Overview:}

This chapter provides the findings of this study and is segmented into 2 parts. The first part quantitative results observed in this study, followed by the interview findings. 


\section{Quantitative findings:}

\section{Demographics:}

The demographics of this study can be found in the table below:

Table 1. Demographics

\begin{tabular}{|l|l|}
\hline Category & Percentage \\
\hline Male & $69 \%$ \\
\hline Female & $31 \%$ \\
\hline Below 20 years & $20 \%$ \\
\hline 20-22 years & $65 \%$ \\
\hline Above 22 years & $15 \%$ \\
\hline Urban areas & $64 \%$ \\
\hline Rural areas & $36 \%$ \\
\hline Program enrolled & \\
\hline Business Administration & $22.7 \%$ \\
\hline Computer Science & $21.3 \%$ \\
\hline Software Engineering & $16.4 \%$ \\
\hline Computer engineering & $14.5 \%$ \\
\hline Electrical engineering & $14.4 \%$ \\
\hline Telecommunication engineering & $10.2 \%$ \\
\hline
\end{tabular}

\section{Management quality and student's satisfaction:}

First analysis was carried out to check the relationship between Management quality and student satisfaction. According to the findings observed, following results are obtained:

Variables Entered/Removed
\begin{tabular}{|l|l|l|l|}
\hline Model & $\begin{array}{c}\text { Variables } \\
\text { Entered }\end{array}$ & $\begin{array}{c}\text { Variables } \\
\text { Removed }\end{array}$ & Method \\
\hline 1 & SC $^{b}$ & & Enter \\
\hline
\end{tabular}

a. Dependent Variable: $S Q$

b. All requested variables entered.

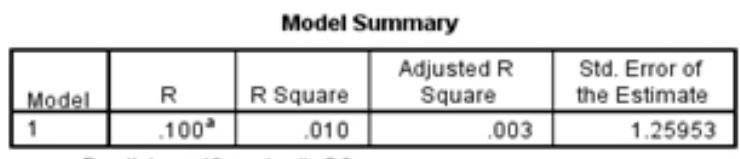

a. Predictors: (Constant), SC

\begin{tabular}{|c|c|c|c|c|c|c|}
\hline \multicolumn{7}{|c|}{ ANOVA $^{3}$} \\
\hline \multicolumn{2}{|c|}{ Model } & $\begin{array}{l}\text { Sum of } \\
\text { Squares }\end{array}$ & df & Mean Square & $\mathrm{F}$ & Sig. \\
\hline \multirow[t]{3}{*}{1} & Regression & 2.384 & 1 & 2.384 & 1.502 & $.222^{\mathrm{b}}$ \\
\hline & Residual & 234.790 & 148 & 1.586 & & \\
\hline & Total & 237.173 & 149 & & & \\
\hline
\end{tabular}

a. Dependent Variable: $S Q$

b. Predictors: (Constant), SC

Figure 2. Management quality and students' satisfaction 
The results above show that most of the students are not satisfied with the Management quality provided to them by the university management. They argued that the university management is not providing them support and because of that Management quality observed is significantly low. The value of significance is greater than 0.05 , hence the students are not satisfied with the Managements provided to them by the university management. The value of correlation is also observed in the following fashion:

\section{Correlations}

\begin{tabular}{|ll|r|r|}
\hline & & \multicolumn{1}{|c|}{ SQ } & \multicolumn{1}{c|}{ SC } \\
\hline SQ & Pearson Correlation & 1 & .100 \\
& Sig. (2-tailed) & & .222 \\
& N & 150 & 150 \\
\hline SC & Pearson Correlation & .100 & 1 \\
& Sig. (2-tailed) & .222 & \\
& N & 150 & 150 \\
\hline
\end{tabular}

Figure 3. Correlation between Management quality and student's satisfaction

Correlation is found to be positive with a value of 0.100 , hence it can be argued that Management quality and student's satisfaction is positive. University reputation and student's satisfaction:

The second hypothesis aimed to check the relationship between university reputation and student satisfaction. Following results were obtained:

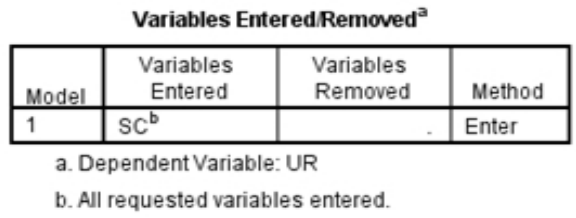

\begin{tabular}{l} 
Model Summary \\
\begin{tabular}{|l|l|r|r|r|}
\hline Model & R & R Square & $\begin{array}{c}\text { Adjusted R } \\
\text { Square }\end{array}$ & $\begin{array}{c}\text { Std. Error of } \\
\text { the Estimate }\end{array}$ \\
\hline 1 & $.036^{\text {a }}$ & .001 & -.005 & 1.29616 \\
\hline
\end{tabular} \\
\hline
\end{tabular}

\begin{tabular}{|c|c|c|c|c|c|c|}
\hline \multicolumn{7}{|c|}{ ANOVA $^{a}$} \\
\hline & & $\begin{array}{l}\text { Sum of } \\
\text { Squares }\end{array}$ & df & Mean Square & $\mathrm{F}$ & Sig. \\
\hline \multirow[t]{3}{*}{1} & Regression & .316 & 1 & .316 & .188 & $.665^{b}$ \\
\hline & Residual & 248.644 & 148 & 1.680 & & \\
\hline & Total & 248.960 & 149 & & & \\
\hline
\end{tabular}

Figure 4. Reputation and students' satisfaction 
The results above indicate that most of the students are unsatisfied with the university reputation because they believe that poor quality of Management contributes to the low level of the workers. The value of significance is significantly higher than 0.05 showing low satisfaction rate.

The correlation between both the variables is found in the following fashion:

\section{Correlations}

\begin{tabular}{|ll|r|r|}
\hline & & \multicolumn{1}{|c|}{ UR } & \multicolumn{1}{c|}{ SC } \\
\hline UR & Pearson Correlation & 1 & -.036 \\
& Sig. (2-tailed) & & .665 \\
& N & 150 & 150 \\
\hline SC & Pearson Correlation & -.036 & 1 \\
& Sig. (2-tailed) & .665 & \\
& N & 150 & 150 \\
\hline
\end{tabular}

Figure 5. University reputation and students' satisfaction

The university reputation and students' satisfaction are not directly related to each other, because the value observed is negative.

\section{Price and student's satisfaction:}

This hypothesis aimed to evaluate the relationship between student's satisfaction and price to come out with the following results:

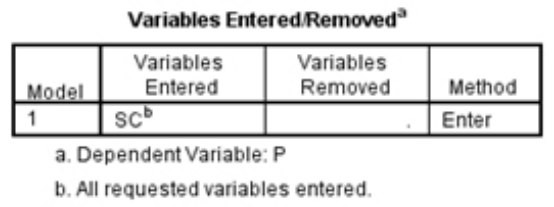

\begin{tabular}{|l|l|r|r|r|}
\hline Model Summary \\
\hline Model & R & R Square & $\begin{array}{c}\text { Adjusted R } \\
\text { Square }\end{array}$ & $\begin{array}{c}\text { Std. Error of } \\
\text { the Estimate }\end{array}$ \\
\hline 1 & $.025^{3}$ & .001 & -.006 & 1.44875 \\
\hline
\end{tabular}
a. Predictors: (Constant), SC

\begin{tabular}{|c|c|c|c|c|c|c|}
\hline \multicolumn{7}{|c|}{ ANOVA $^{\mathrm{a}}$} \\
\hline & & $\begin{array}{l}\text { Sum of } \\
\text { Squares }\end{array}$ & df & Mean Square & $\mathrm{F}$ & Sig. \\
\hline \multirow{3}{*}{1} & Regression & .199 & 1 & .199 & .095 & $.758^{b}$ \\
\hline & Residual & 310.634 & 148 & 2.099 & & \\
\hline & Total & 310.833 & 149 & & & \\
\hline
\end{tabular}

Figure 6. Price and student's satisfaction 
The results obtained show that value of significance is once again significantly high, because of which it can be argued that most of the students are unhappy with tuition fees and other miscellaneous charges, which are imposed by the university. The value of significance is more than 0.05 , hence most of the students answered the questions negatively.

The correlation between Price and student's satisfaction is observed in the following fashion:

\section{Correlations}

\begin{tabular}{|ll|r|r|}
\hline & & SC & \multicolumn{1}{c|}{ P } \\
\hline SC & Pearson Correlation & 1 & .025 \\
& Sig. (2-tailed) & & .758 \\
& N & 150 & 150 \\
\hline P & Pearson Correlation & .025 & 1 \\
& Sig. (2-tailed) & .758 & \\
& N & 150 & 150 \\
\hline
\end{tabular}

Figure 7. Correlation between Price and student's satisfaction

Correlation between price and students' satisfaction is positive because its value is 0.025 . therefore, Price and student's satisfaction are positively related to each other.

\section{University culture and student's satisfaction:}

The fourth hypothesis aimed to investigate university culture and its relationship with student's satisfaction to depict following results:

Variables Entered/Removed
\begin{tabular}{|l|c|c|c|}
\hline Model & $\begin{array}{c}\text { Variables } \\
\text { Entered }\end{array}$ & $\begin{array}{c}\text { Variables } \\
\text { Removed }\end{array}$ & Method \\
\hline 1 & SC $^{b}$ & & Enter \\
\hline
\end{tabular}
a. Dependent Variable: UC
b. All requested variables entered.

\begin{tabular}{l} 
Model Summary \\
\begin{tabular}{|l|c|r|r|r|}
\hline Model & $R$ & R Square & $\begin{array}{c}\text { Adjusted R } \\
\text { Square }\end{array}$ & $\begin{array}{c}\text { Std. Error of } \\
\text { the Estimate }\end{array}$ \\
\hline 1 & $.151^{2}$ & .023 & .016 & 1.24125 \\
\hline
\end{tabular} \\
\hline
\end{tabular}

ANOVA ${ }^{3}$

\begin{tabular}{|ll|r|r|r|r|r|}
\hline Model & & $\begin{array}{l}\text { Sum of } \\
\text { Squares }\end{array}$ & df & Mean Square & F & Sig. \\
\hline 1 & Regression & 5.318 & 1 & 5.318 & 3.451 & $.065^{5}$ \\
& Residual & 228.022 & 148 & 1.541 & & \\
& Total & 233.340 & 149 & & & \\
\hline
\end{tabular}

a. Dependent Variable: UC

b. Predictors: (Constant), SC

Figure 8. University culture and students' satisfaction 
The results are similar to previous ones also. Most of the questions were negatively responded by the students because they did not like university culture and wants it to change. The value of significance is greater than 0.05 , and it can be argued that university culture is not helping the students to overcome the problems of satisfaction.

The correlation between the two variables is illustrated below:

\section{Correlations}

\begin{tabular}{|ll|r|r|}
\hline & & UC & \multicolumn{1}{c|}{ SC } \\
\hline UC & Pearson Correlation & 1 & .151 \\
& Sig. (2-tailed) & & .065 \\
& N & 150 & 150 \\
\hline SC & Pearson Correlation & .151 & 1 \\
& Sig. (2-tailed) & .065 & \\
& N & 150 & 150 \\
\hline
\end{tabular}

Figure 9. University culture and students' satisfaction

The results show a positive correlation between the two variables. The value of correlation comes out to be 0.151 , hence the fourth hypothesis is also accepted.

\section{Relationship between Role of government and quality management:}

When the questions related to role of government and quality management were inquired from the respondents, following results were obtained:

\begin{tabular}{|l|l|l|c|c|}
\multicolumn{7}{|c|}{ Model Summary } \\
\hline Model & $\mathrm{R}$ & R Square & $\begin{array}{c}\text { Adjusted } \mathrm{R} \\
\text { Square }\end{array}$ & $\begin{array}{c}\text { Std. Error of } \\
\text { the Estimate }\end{array}$ \\
\hline 1 & $.885^{\mathrm{a}}$ & .782 & .781 & .25818 \\
\hline
\end{tabular}

Predictors: (Constant), ROG

ANOVA ${ }^{\text {a }}$

\begin{tabular}{|rl|r|r|r|r|c|}
\hline & & $\begin{array}{c}\text { Sum of } \\
\text { Squares }\end{array}$ & \multicolumn{1}{c|}{ df } & Mean Square & \multicolumn{1}{c|}{ F } & Sig. \\
\hline 1 & Regression & 35.468 & 1 & 35.468 & 532.100 & $.000^{\mathrm{b}}$ \\
& Residual & 9.865 & 148 & .067 & & \\
& Total & 45.333 & 149 & & & \\
\hline
\end{tabular}

a. Dependent Variable: $Q M$

b. Predictors: (Constant), ROG

\begin{tabular}{|c|c|c|c|c|c|c|}
\hline \multicolumn{7}{|c|}{ Coefficients $^{a}$} \\
\hline \multirow{2}{*}{\multicolumn{2}{|c|}{ Model }} & \multicolumn{2}{|c|}{ Unstandardized Coefficients } & \multirow{2}{*}{$\begin{array}{c}\begin{array}{c}\text { Standardized } \\
\text { Coefficients }\end{array} \\
\text { Beta }\end{array}$} & \multirow[b]{2}{*}{$\mathrm{t}$} & \multirow[b]{2}{*}{ Sig. } \\
\hline & & $\mathrm{B}$ & Std. Error & & & \\
\hline & (Constant) & .069 & .149 & & .464 & .644 \\
\hline & ROG & .973 & .042 & .885 & 23.067 & .000 \\
\hline
\end{tabular}

Figure 10. Role of government and quality management 
The results above show that value of significance is highly significant. The value of regression is observed to be 0.000 , which shows a high significance between the two variables. the value of correlation is also presented in the figure below:

\section{Correlations}

\begin{tabular}{|ll|r|r|}
\hline & & \multicolumn{1}{|c|}{ ROG } & \multicolumn{1}{c|}{ QM } \\
\hline ROG & Pearson Correlation & 1 & $.885^{\wedge \times}$ \\
& Sig. (2-tailed) & & .000 \\
& N & 150 & 150 \\
\hline QM & Pearson Correlation & $.885^{\star \times}$ & 1 \\
& Sig. (2-tailed) & .000 & \\
& N & 150 & 150 \\
\hline
\end{tabular}

**. Correlation is significant at the 0.01 level (2tailed).

Figure 11. Correlation between ROG and QM

The results above show that there is a positive correlation between role of government and quality management. The value observed is 0.885 , hence increasing role of government will also increase quality management in the academics.

\section{Relationship between role of institutions and quality management:}

The relationship between the role of institutions and quality management is observed below:

\begin{tabular}{l}
\begin{tabular}{|l|l|c|c|c|}
\hline Model & R & R Square & $\begin{array}{c}\text { Adjusted R } \\
\text { Square }\end{array}$ & $\begin{array}{c}\text { Std. Error of } \\
\text { the Estimate }\end{array}$ \\
\hline 1 & $.038^{\text {a }}$ & .001 & -.005 & .55305 \\
\hline
\end{tabular} \\
\hline
\end{tabular}

\begin{tabular}{|c|c|c|c|c|c|c|}
\hline \multicolumn{7}{|c|}{ ANOVA $^{a}$} \\
\hline & & $\begin{array}{l}\text { Sum of } \\
\text { Squares }\end{array}$ & df & Mean Square & $\mathrm{F}$ & Sig. \\
\hline \multirow[t]{3}{*}{$\frac{M}{1}$} & Regression & .066 & 1 & .066 & .216 & $.643^{b}$ \\
\hline & Residual & 45.267 & 148 & .306 & & \\
\hline & Total & 45.333 & 149 & & & \\
\hline
\end{tabular}

a. Dependent Variable: $Q M$

b. Predictors: (Constant), ROI

\begin{tabular}{|c|c|c|c|c|c|c|}
\hline \multicolumn{7}{|c|}{ Coefficients $^{a}$} \\
\hline \multirow{2}{*}{\multicolumn{2}{|c|}{ Model }} & \multicolumn{2}{|c|}{ Unstandardized Coefficients } & \multirow{2}{*}{$\begin{array}{c}\text { Standardized } \\
\text { Coefficients } \\
\text { Beta }\end{array}$} & \multirow[b]{2}{*}{$\mathrm{t}$} & \multirow[b]{2}{*}{ Sig. } \\
\hline & & $\mathrm{B}$ & Std. Error & & & \\
\hline & (Constant) & 3.411 & .128 & & 26.651 & .000 \\
\hline & ROI & .016 & .034 & .038 & .465 & .643 \\
\hline
\end{tabular}

a. Dependent Variable: QM

Figure 12. Institutions and quality management 
The relationship observed above shows that quality management and role of institutions is very weak and standing at a value of 0.643 . Therefore, the institutions are not supported by the students and received negative rating from the management side. The value of correlation can be found in the figure below:

\begin{tabular}{|} 
Correlations \\
\begin{tabular}{|ll|r|r|}
\hline & \multicolumn{1}{c|}{ ROI } & \multicolumn{1}{c|}{ QM } \\
\hline ROI & Pearson Correlation & 1 & .038 \\
& Sig. (2-tailed) & & .643 \\
& N & 150 & 150 \\
\hline QM & Pearson Correlation & .038 & 1 \\
& Sig. (2-tailed) & .643 & \\
& N & 150 & 150 \\
\hline
\end{tabular}
\end{tabular}

Figure 13. Correlation between institutions and quality management

The value of correlation is positive, due to which it can be argued that institutions should follow some practices which can increase quality management since it is positively associated.

\section{Summary of Hypotheses:}

Table 2. Hypotheses results

\begin{tabular}{|l|l|}
\hline Hypothesis & Accepted \\
\hline Management quality and students' satisfaction are positively associated. & Accepted \\
\hline University reputation influences students' satisfaction positively. & Rejected \\
\hline Price influences students' satisfaction positively. & Accepted \\
\hline University culture influences students' satisfaction positively. & Accepted \\
\hline $\begin{array}{l}\text { Role of Government and quality management in public universities is } \\
\text { important }\end{array}$ & Accepted \\
\hline $\begin{array}{l}\text { Role of institutions and quality management in public universities is } \\
\text { important }\end{array}$ & Accepted \\
\hline
\end{tabular}

\section{Interview Results:}

The interview results are segmented in this section based on the questions related to New Institutionalism theory:

While answering question 1, out of the 10 participants, 8 argued that management of new institutions should start focusing on new institutionalism theory because it is a new theory and provides new sociological views of managing the students. According to them, this theory can significantly elevate the performance of the workers because it has necessary steps of managing the students along with their benefits. Only 2 participants said that 
this theory does not have a framework to carry out the required support for the management of institutions.

When second question related to environmental benefits of this theory were inquired, 6 people argued that this theory supports open environment and communication. They said that open communication allows the students to get their issues resolved quickly and sustain them. However, 4 participants remained confused whether open environment in university would increase management quality or not. They argued that this theory does not allow legitimacy, and recommended that university must be having enough revenues to sustain this method of implementation for improving the workplace environment.

In response to the third question, which investigated the role of this theory in the development of human behaviours, rules and norms, 8 respondents stated that institutions should be having the required workforce for the development of this theory. They supported this theory by saying that it allows passive influence and allow the development of platforms which results in complying with academic rules and procedures. Hence, if the management of university is willing to increase its management quality, it should focus on the development of a platform, which is supported by policies providing both tangible and intangible benefits.

Another question was inquired related to finding out how the management of an institute can use this theory to improve its infrastructure. $60 \%$ of the respondents argued that management should be forced to follow the policies of the institute, and a monitor should be there to check their performance regularly. This theory allows monitoring of the workers, therefore, if it is used, chances of increasing efficiencies and affectivity of students' support would significantly increase.

Last question was related to how many institutions in Pakistan are following this theory in their premises. $90 \%$ of the respondents said that this theory is rarely followed in universities of Pakistan, even when it carries potential to resolve many problems within itself. However, one participant stated that he did not know about this ratio. Therefore, it can be argued that this theory can be used for generating potential benefits, however, the management should be provided with awareness of potential benefits of this theory.

\section{Discussion and Recommendations:}

After careful evaluation of the research results, it can be said that most of the students are not satisfied, because most of them answered the questions negatively.

In hypothesis number one, the students were inquired with the following questions: 
- Your university provides quick Managements when required.

- Your university has a hierarchy in Management provision and willingly resolves all the problems of the students.

In response to the statements above, most of the students answered negatively and said that they were not happy with the Management provided to them by the university management. The results obtained were similar to Qazi, Raza and Shah (2018) and Sharif, Afshan and Qureshi (2019), who wrote that Management quality is positively related with satisfaction, however, not focused by many universities.

When the respondents of this study were inquired with the questions related to the second hypothesis, following observations were made:

- Your university has a good reputation in the market because of high student's satisfaction rate.

- Your university has been famous for providing support to their students and that too with increased support.

The responses received for the above questions were mostly negative, and students did not support the arguments that university reputation is attached to their satisfaction rate, as the hypothesis was rejected. The results were similar to Junejo and Muhammad (2018) but different from Bates, Kaye and McCann (2019) and Torlak and Kuzey (2019).

The third hypothesis inquired whether price has an influence on students' satisfaction. The following questions were inquired:

- You are satisfied with pricing policies of HEC.

- You can easily afford the tuition fee for the semester.

The respondents mostly belonged to the private institutions and argued that they were not happy with the pricing structure of the universities. However, a positive correlation was observed between the variables. The responses were similar to Ali, Ulah and Sanauddin (2019) and Ud Din and Saeed (2019) also. Both the studies argued that universities in Pakistan charge a lot from their students and most of the students cannot afford.

The fourth hypothesis aimed to evaluate the relationship between university culture and students satisfaction. Following statements were inquired:

- The culture in university is supportive and you are satisfied with them.

- All the staff members and teachers are easily approachable within the university premises.

The answers supported the statement that the students were not happy with the support provided to them by the university management and rated it negatively. The results were not supporting the statement that universities of Pakistan are supportive, hence it has become difficult to increase the satisfaction level of the workers. The study of Ali, Sulaiman and Javed (2018) 
supported similar results, while Fatima and Khero (2019) reported other factors, which contribute to the students' satisfaction.

After careful evaluation of the research aims and objectives, it can be argued that most of the students did not support university culture, tuition fee, reputation and services provided to them. The culture is not supportive and several changes are needed by the management. With an increase in challenges in educational fields, it would be necessary for the teachers to follow an appropriate method of teaching and the management to improve service quality, otherwise, the supportive leadership style would fail. Especially against increasing fees, service quality must also increase in order to overcome the challenges of future. The reputation of a university significantly relies on the approaches it takes to support the academic education platform and to elevate service category for the students, otherwise, an increment in university fee would only be elevating the concerns of the teachers and management due to leaving students.

The relationship between university culture, price, service quality and reputation are obtained to be positive, therefore, the management of university should focus on these parameters to engage in the activities. positive culture and supportive management would increase service quality, and the students will then happily pay the fee to the university due to high satisfaction level from service delivery and supportive culture.

\section{Limitations and Further Studies:}

This study was limited to analysing university culture, price, management quality, and other relevant parameters. The investigation to other parameters such as registration process, hurdles in meeting the teachers, and the support provided by HEC should also be investigated in future. The sample size should be increased in future because many students study in different universities not focused on this investigation. The university culture must be investigated by looking at many other parameters, such as events and organisations coming to the university for hiring. University reputation should be assessed by looking at the jobs offered to its graduates. These are recommendations for future studies. This study did not present comparison of different universities and their culture, price etc. which should be done by future investigators.

\section{Conclusion}

After critical evaluation of the research aims and objectives, it can be concluded that the management of HEC is not providing support to the students. The students are not happy with the support provided to them by their universities and rates them negatively. Conclusively, the association between student satisfaction and Management quality is positive, however, students are not happy with timely Management and its quality. In addition, the 
relationship between university reputation is observed to be negative and students answered these questions negatively. Another important conclusion, which should be made is that the management of various institutions should indulge in discussion and come up with an improved pricing structure because most of the students do not like it. In Pakistan, most of the students cannot afford private education because of significantly high fees, therefore, they need to improve it. The culture is also non-collaborative and the management should start focusing on it to increase students' satisfaction.

\section{References:}

1. Ahangaran, M. R., Afshar, A., \& Ghaed, M. (2016). Evaluating the cultural management of Islamic dressing at universities (Case study: Evaluating the attitude of students (girls and boys) of Islamic Azad University, Central Tehran Branch). Iranian Journal of Management Studies, 9(1), 193-215.

2. Ali, A. Y. S., \& Mohamed, A. I. (2014). Management quality provided by higher education institutions in Somalia and its impact on student satisfaction. European Journal of Business and Management, 6(11), 143-148.

3. Ali, A., Sulaiman, N., \& Javed, M. (2018). Employers' Satisfaction with Professionally Qualified Secondary School Teachers in Pakistan. Journal of Educational Research (1027-9776), 21(1). 1-9.

4. Ali, J., Ullah, H., \& Sanauddin, N. (2019). Postgraduate Research Supervision: Exploring the Lived Experience of Pakistani Postgraduate Students. FWU Journal of Social Sciences, 13(1). 1-9

5. Andam, R., Montazeri, A., Feizi, S., \& Mehdizadeh, R. (2015). Providing a multidimensional measurement model for assessing quality of sport tourism Managements: Empirical evidence from sport conference as sport event tourism. Iranian Journal of Management Studies, 8(4), 607-629.

6. Arif, M., Ameen, K., \& Rafiq, M. (2018). Factors affecting student use of Web-based Managements: Application of UTAUT in the Pakistani context. The Electronic Library, 36(3), 518-534.

7. Arif, S., Iqbal, J., \& Khalil, U. (2019). Factors Influencing Students' Choices of Academic Career in Pakistan. FWU Journal of Social Sciences, 13(1). 12-20.

8. Azizi, S., Kapak, S. J., \& Tarhandeh, F. (2014). Physical distribution Management quality through Iranian convenience stores retailers' perspectives: A mixed method approach. Iranian Journal of Management Studies, 7(1), 121-150.

9. Babaei, D., Rahimian, H., Ahmad, A., Omar, Z., \& Idris, K. (2015). Ability mediation effects in the relationships between human resource 
practices and Management quality. Iranian Journal of Management Studies, 8(1), 5-25.

10. Bates, E. A., Kaye, L. K., \& McCann, J. J. (2019). A snapshot of the student experience: exploring student satisfaction through the use of photographic elicitation. Journal of Further and Higher Education, 43(3), 291-304.

11. Dib, H., \& Alnazer, M. (2013). The impact of Management quality on student satisfaction and behavioral consequences in higher education Managements. International Journal of Economy, Management and Social Sciences, 2(6), 285-290.

12. Enayati, T., Modanloo, Y., Behnamfar, R., \& Rezaei, A. (2013). Measuring Management quality of Islamic Azad University of Mazandaran using SERVQUAL Model. Iranian Journal of Management Studies, 6(1), 99-116.

13. Fatima, M., \& Khero, M. (2019). Factors Impacting the Student's Loyalty: An Empirical Investigation of Higher Education Sector In Pakistan. International Journal of Entrepreneurial Research, 1(2), 1-7.

14. Ferdousipour, L. (2016). The relationship among public Management motivation, Civic-Organizational Behavior (OBC), and Management quality. Iranian Journal of Management Studies, 9(1), 1-20.

15. Junejo, I., \& Muhammad, J. (2018). An Exploration of Factors Affecting the Motivation of Post-Graduate Research in Sindh: Students' Perception. Journal of Management Info, 5(4), 21-25.

16. Kordshouli, H. R., Jafarpour, Y., \& Bouzanjani, A. A. (2016). An analysis of the pro-social behaviors of customers in response to the firms' Management quality. Iranian Journal of Management Studies, 9(1), 21-41.

17. Ntabathia, M. (2013). Management quality and student satisfaction of students in private universities in Nairobi County. A Research Project for MBA Degree, Nairobi, Kenya.

18. Qazi, W., Raza, S. A., \& Shah, N. (2018). Acceptance of e-book reading among higher education students in a developing country: the modified diffusion innovation theory. International Journal of Business Information Systems, 27(2), 222-245.

19. Raza, S. A., Qazi, W., \& Shah, N. (2018). Factors affecting the motivation and intention to become an entrepreneur among business university students. International Journal of Knowledge and Learning, 12(3), 221-241.

20. Shah, F. T. (2013). Management quality and Management satisfaction. Journal of Quality and Technology Management, 9(2), 73-89.

21. Sharif, A., Afshan, S., \& Qureshi, M. A. (2019). Acceptance of learning management system in university students: an integrating 
framework of modified UTAUT2 and TTF theories. International Journal of Technology Enhanced Learning, 11(2), 201-229.

22. Sin, M. C., Yusof, B. B., \& Sin, K. Y. (2018). International Students' Satisfaction Level towards Management Quality in Academic Aspect and Loyalty to Universiti Teknologi Malaysia. INTERNATIONAL JOURNAL OF ACADEMIC RESEARCH IN BUSINESS AND SOCIAL SCIENCES, 8(10). 22-30.

23. Torlak, N.G. \& Kuzey, C., (2019). Leadership, job satisfaction and performance links in private education institutes of Pakistan. International Journal of Productivity and Performance Management, 68(2), 276-295.

24. ud Din, K., \& Saeed, M. (2018). Relationship between University Students' English Proficiency, Academic Achievement and their Satisfaction on Teacher Feedback. Bulletin of Education and Research, 40(3), 129-143.

25. Uprety, R., \& Chhetri, S. B. (2014). College culture and student satisfaction. Journal of Education and Research, 4(1), 77-92.

26. Xu, F., \& Du, J. T. (2018). Factors influencing users' satisfaction and loyalty to digital libraries in Chinese universities. Computers in Human Behavior, 83, 64-72.

\section{Appendices}

\section{Appendix A - Interview questionnaire}

1. Do you believe that New Institutional theory should be used by the academic institutes? Does it provide new sociological views of managing the students?

2. What are the environmental benefits of New Institutional theory in the academic education and how it improves management quality?

3. What is the role of New Institutional theory in the development of human behaviors, rules and norms in academic education?

4. How the management of an institute can use this theory to improve its infrastructure?

5. How many institutions in Pakistan are following this theory in their premises? 